\title{
TESTING FOR TRADE-INDUCED \\ INVESTMENT-LED GROWTH
}

\author{
Richard E. Baldwin \\ Elena Seghezza
}

Working Paper 5416

\section{NATIONAL BUREAU OF ECONOMIC RESEARCH 1050 Massachusetts Avenue \\ Cambridge, MA 02138 \\ January 1996}

We gratefully acknowledge suggestions and comments from Phil Swaigel, Jong-Wha Lee, Linda Goldberg, Ann Harrison, Ed Leamer, Jim Anderson, Jim Levinsohn, and Rob Feenstra. Thanks to Phillipe Martin for help with data sets. The research was supported by the Swiss NSF grant 1214-043580.95/1, and the Ford Foundation support of CEPR's MIRAGE project. This paper is part of NBER's research program in International Trade and Investment. Any opinions expressed are those of the authors and not those of the National Bureau of Economic Research.

(C) 1996 by Richard E. Baldwin and Elena Seghezza. All rights reserved. Short sections of text, not to exceed two paragraphs, may be quoted without explicit permission provided that full credit, including $\odot$ notice, is given to the source. 


\title{
TESTING FOR TRADE-INDUCED \\ INVESTMENT-LED GROWTH
}

\begin{abstract}
Many studies have found a positive correlation between trade and growth, but do not attempt to identify the economic mechanisms involved. This paper attempts to identify one of the mechanisms linking trade and growth. In particular, we present a novel theoretical model that establishes a link between trade liberalization and investment-led growth. Estimating equations are derived from the model and estimated with three stage least squares on a cross-country data sample. We find that domestic protection depresses investment and thereby slows growth. Foreign trade barriers also lower domestic investment, but the anti-investment effect is weaker and is less robust to sample and specification changes.
\end{abstract}

Richard E. Baldwin

Graduate Institute of International Studies 11a, avenue de la Paix

1202 Geneva

SWITZERLAND

and NBER
Elena Seghezza

Graduate Institute of International Studies

11a, avenue de la Paix

1202 Geneva

SWITZERLAND 
Date Printed $=12$ December 1995 Version=c:|wpfiles\_emp_grolaer-fin __ntech.sum Version date $=12 / 12 / 95$

\section{Testing for Trade-Induced, Investment-led Growth}

Richard E. Baldwin and Elena Seghezza

Graduate Institute of International Studies, University of Geneva

\section{NON-TECHNICAL SUMMARY}

This paper presents a novel theoretical trade and growth model that emphases the role of traded intermediates employed in the capital formation sector and the capital intensity of traded versus nontraded sectors. The model is used to generate estimating equations, which are then estimated on cross-country data with multi-equation instrumental variable techniques.

The core economic mechanism in the theoretical model is the link between trade barriers and the derived demand for capital. The model is dynamic, but intuition is boosted by first considering a static trade model. As is well known, domestic and foreign trade barriers alter capital's rental rate by shifting the general equilibrium derived demand for the fixed capital stock. For instance, if the import-competing sector is relative intensive in its use of capital, domestic protection raises the rental rate. If exports are also capital intensive, then foreign barriers tend to lower the rental rate. Of course with intraindustry trade, it is possible for both imports and exports to be more capital intensive than nontraded goods. (The paper present some evidence that this is true for the US, Japan and the UK.) If we relax the fixed factor supply assumption and allow endogenous capital accumulation, trade policy can affect investment and thereby output growth. In a neoclassical growth framework this leads to medium-run investment and growth effects. In an endogenous growth setup, it may have permanent growth effects.

As articulated, however, the model has merchantilist implications. Raising home barriers and lowering foreign barriers unambiguously stimulates the demand for home capital and thereby leads to trade-induced investment-led growth. Since this prediction does not fit the facts, we add another element that has long played an important role in the trade and growth literature, namely imported capital goods. We suppose the capital goods sector uses traded intermediate inputs, so the price of imports and locally produced substitutes affect the cost of new capital. In this case, domestic protection acquires an anti-investment aspect that counters the above mentioned pro-investment effect. Specifically, assuming that traded goods are an input into capital formation, protection raises the cost of new capital goods and thereby tends to lower the rate of return on investment. With intertemporal optimization, this lowers the steady-state capital stock and slows growth in the transition. The net effect of domestic protection on growth is ambiguous, a matter for empirical investigation. 
Note our theoretical model provides a solution to empirical puzzle posed by Levine and Renelt (1992). Using single equation OLS estimating techniques on equations that are specified on an ad hoc basis, Levine and Renelt (1992) find that openness is correlated with high investment rates, but not with high GDP growth when investment is included in the growth equation. They find this puzzling since they assert that the theoretical ties between growth and trade typically seem to run through improved resource allocation and not through higher physical investment share. Our model shows that openness can affect return to investment (and thereby the investment rate) by altering capital's rental rate and by altering the cost of new capital.

\section{Empirical Results}

Growth and investment equation are derived from the model and estimated with threestage least squares on a cross-country sample of manufacture exporters. We find that domestic barriers depress investment and thereby growth. This result is fairly robust in that it is present in a variety of sample and for a variety of openness proxies. Foreign trade barriers are also found to depress investment and growth, but the effect is less strong and much less robust to sample and proxy changes, than that of domestic protection.

Furthermore, we find no evidence for trade-induced technology-led growth. More precisely, system estimation of the growth and investment equations find that trade barrier variables are not significant in the growth equation when they are also included in the investment equation. This finding is confirmed on a variety of data samples and for a variety of trade barrier proxies. These empirical result are very much in line with the results obtain by Levine and Renelt (1992) using OLS estimation of the individual equations. Finally, we run a true reduced-form growth regression -- that is one in which only exogenous variables are included on the right-hand side. Results from this reduced-form regression show that domestic and foreign trade barriers do slow growth.

The lack of significance of trade variables in the growth equation, suggests that trade does not affect growth by boosting the rate of technology progress. However, our results are far from conclusive evidence against trade-induced technology-led growth. We interpret the results as saying that this sort of productivity effect is not strong enough to show up in such a broad cross-section data set, even though the investment effect is. More technically, the error term in the growth equation is almost surely not white noise. It includes inter alia all factors influencing technological progress except those due to the technology gap captured by the initial $\mathrm{Y} / \mathrm{L}$ variable. These omitted factors are likely to be correlated with many of the variables included in the basic regression. For instance, in many growth models, the rate of knowledge accumulation is proportional to the rate of physical capital formation. Thus with physical capital accumulation linearly related to investment, the estimated coefficient on the investment variable may be picking the influence of the omitted knowledge creation variable. In other words, it may be that there is such a close correlation between $\mathrm{K}$ investment and technological progress that it is impossible to disentangle the impact of trade on innovation in a growth equation. A superior approach - adopted by Coe and Helpman (1995) would be to work with a measure of technological progress such as total factor productivity growth and use time series data. 


\section{Testing for Trade-Induced, Investment-led Growth}

\section{Introduction}

Most economists and policy makers believe that international commerce, especially trade in goods, provides important benefits to the nations participating in world trade. This belief is founded on the experience of nations. At a very broad level, nations that embraced international commerce have grown while those that shunned it have stagnated. Many theoretical models have been developed to analyze this trade and growth nexus. This paper adds one more model, however the primary aim of our theory is to derive estimating equations rather than illustrate a new economic mechanism, or explore the boundaries of existing models.

The core mechanism in the model is the link between trade barriers and the derived demand for capital. Our model is dynamic, but intuition is gained by considering a static, fixed factor-supply framework in which domestic and foreign trade barriers can affect the derived demand for domestic capital. Domestic protection typically expands output in the import-competing sector. If this sector is capital intensive, the production expansion boosts the derived demand for home capital. With a fixed capital stock, the net result is a higher domestic rental rate. If exports are also capital intensive, then foreign barriers tend to lower the domestic rental rate by the same mechanism. Of course, with intraindustry trade both imports and exports can be capital intensive. The only requirement is that traded goods are capital intensive relative to nontraded goods.

In a dynamic framework with endogenous capital accumulation, this same mechanism 
creates a link between protection, investment and growth. In a neoclassical growth framework this leads to medium-run investment and growth effects.

As articulated, the model has merchantilist implications. Raising home barriers and lowering foreign barriers unambiguously leads to trade-induced investment-led growth. Since this prediction contradicts empirical findings, a mechanism that gives an antiinvestment aspect to domestic protection is necessary to bring the model in line with the evidence. Imported capital goods, which have long played an important role in the trade and growth literature, serve admirably.' When imports and locally produced substitutes are inputs into capital formation, domestic protection can discourage investment by raising the cost of new capital goods (thereby lowering the rate of return on investment). With intertemporal optimization on consumption, this tends lowers the steady-state capital stock and slows growth in the transition.

The plan of the paper is as follows. The rest of section 1 reviews some closely related empirical studies and evidence on capital intensity of traded versus nontraded goods. Section 2 present the theoretical model. Section 3 derives the estimating equations and discusses data issues. Section 4 presents the results. The final section presents a summary and our concluding remarks.

\section{A. Brief Review of the Empirical Literature}

The empirical literature on trade and growth is vast. Early studies are well-reviewed by Edwards (1993), and more recent studies by Harrison (1995), so we limit ourselves attention to the studies that have guided our modelling choices. In a review of crosscountry growth regressions, Levine and Renelt (1992) find that none of the seven standard measures of trade openness in their data sets are robustly related to GDP growth. They do find, however, that five trade/openness variables are robustly related to investment-GDP ratios. These are the export and import to GDP ratios, two openness variables generated by Leamer (1988), and a proxy for terms of trade shocks. Indeed these openness measures are the only variables that have a robust relationship to the investment share, except for the average number of coups and revolutions. In

\footnotetext{
${ }^{1}$ See, for instance, Cairncross (1962) and more recently Lee (1993, 1994).
} 
summarizing this pair of results, the Levine and Renelt note: "These results suggest an important two-link chain between trade and growth through investment. Interestingly, however, the theoretical ties between growth and trade typically seem to run through improved resource allocation and not through higher physical investment share."

Our theoretical model is intended to remedy this lack of a theoretical tie between trade policy, investment and growth. Our empirical results confirm the Levine-Renelt findings that in cross-country data, trade seems to affect growth mainly through its effect on the investment/GDP ratio rather than directly, or via its impact on total factor productivity growth.

Further evidence on the nature of the trade-investment-growth link can be gleaned from De Long and Summers (1991). This study explores the empirical link between equipment investment and GDP per capita growth. They point out that over $30 \%$ of the US equipment purchases are imported, so it is easy to suspect that trade may affect growth especially via its impact on equipment investment. Morcover, they find a strong negative correlation between the equipment prices and growth. Although they present no formal reasoning or model of any kind, their empirical findings suggest a tradeinvestment-growth link. Namely competition from trade can kept domestic equipment prices low, thereby increasing the rate of return to new capital formation. This result was the main motivation for including a channel in our model that allows protection to affect the real price of capital.

Lee $(1992,1994)$ provide support for the empirical relevance of the link between trade policy and the cost of capital goods. These papers are also close to ours in that they use formal growth models to generate the regression specification and provide an economic interpretation of the estimated coefficients. These models, however, are quite different to ours in that they do not consider foreign trade policy and they do not allow for intraindustry trade. The later shortcoming is important for two reasons. First, the bulk of world trade is intraindustry. Second, models without two-way trade in similar products will predict that global trade liberalization would tend to raise the return to capital in some countries and lower it in others (à la Stolper-Samuelson). Since multilateral growth seems to have accompanied multilateral trade liberalization, it seems desirable to work with a model that allows for intraindustry trade. 


\section{B. Capital Intensity of Traded and NonTraded Goods}

A key assumption in our theoretical model is that traded sectors are more capital intensive that nontraded sectors. Indeed if the nontraded sectors were more intensive in their use of physical capital, liberalization would have an anti-investment effect. Our estimating equations are general enough to allow for such a result, however our interpretations of the results rest on the assumed intensities. Consequently, we review some direct evidence supporting the assumption. For the US, Japan and the UK, Table 1 shows two types of value added shares that may be interpreted as measures of capital intensity: Sectoral payments to capital as a share of sectoral value added and sectoral payments to capital plus sectoral operating surplus as a share of value added. The third column for each country shows the importance of the sector in the economy.

The table shows that sectors differ widely in their capital intensities and that there is no simple connection between tradability and capital intensity. By far the most capital intensive is mining and minerals and this is clearly a trade sector. The second most capital intensive is utilities (electricity, gas and water) and this is clearly nontraded, at least for the countries under consideration. The ambiguity disappears when the importance of the sectors is taken into consideration. For instance, utilities plays a negligible role in the economies, while the non-financial service sectors (nontradable) account for between $30 \%$ and $40 \%$ of GDP and have systematically low physical capital intensities. The table also provides average capital intensities of tradable and nontradable sectors, where the sectors are weighted by their share in GDP. In all three countries considered, both measures of average capital intensity show tradables to be relatively capital intensive.

\section{Theoretical Model}

Consider a world of one home and $G$ foreign countries, each with two final goods sectors (manufactured goods and services), a capital formation sector and three factors of production (capital, skilled labour and unskilled labour). Manufactured goods are traded, services and factors are not. Countries have identical tastes, technologies and, initially, identical trade barriers. Countries are endowed with unskilled labour, but 
physical capital $\mathrm{K}$ and human capital $\mathrm{H}$ accumulate. All trade barriers are of the frictional (i.e. iceberg) type, so trade is hindered without generating trade rents. The $X$ sector (manufacturing) consists of $\mathrm{N}$ differentiated products $(\mathrm{N}$ is a constant) while $\mathrm{Z}$ (services) is a homogenous good.

Tastes of the representative consumer in a typical country are:

$$
U_{j}=\int_{0}^{\infty} e^{-\rho t} \ln C(t) d t, \quad C=\left(\lambda^{\lambda}(1-\lambda)^{1-\lambda}\right)\left(C_{X}\right)^{\lambda}\left(C_{Z}\right)^{1-\lambda}
$$

where $C_{X}=\left(\Pi_{i} c_{x i}{ }^{1 N}\right)$; Also $C, C_{Z}, c_{X i}$, and $C_{X}$ are, respectively, consumption of the aggregate consumption index, consumption of services, consumption of variety $\mathrm{i}$ of $\mathrm{X}$, and consumption of the $\mathrm{X}$-sector composite. The perfect price index for $\mathrm{C}$ is $\mathrm{P}=\mathrm{p}_{\mathrm{z}}{ }^{1 \cdot \lambda} \mathrm{P}_{\mathrm{X}}{ }^{\lambda}$, where $P_{X}=\left(\Pi_{i} p_{x i}{ }^{1 / N}\right)$, and $p_{x i}$ and $p_{Z}$ are the price of $X$ variety $i$ and the price of $Z$.

Each of the $\mathrm{N}$ varieties of $\mathrm{X}$ is itself a homogenous goods and is produced according to increasing returns to scale. The producers of each variety play Cournot in each of the $\mathrm{G}+1$ markets (assumed to be segmented). The cost function for a typical $\mathrm{X}$ variety (all varieties are symmetric) is $\mathrm{mX}_{\mathrm{ij}}+\phi \mathrm{w}$, where $\mathrm{m}$ equals $\alpha^{\alpha}(1-\alpha)^{1-\alpha} \mathrm{R}^{\alpha} v^{1 \cdot \alpha}$ where $\mathrm{X}_{\mathrm{ij}}$ is firm j's output of variety $i$, and $v, w, R$ and $\phi$ are the wage rate of skilled and unskilled labour, the rental rate on capital and the overhead component (i.e. a fixed cost flow), respectively. The $Z$ sector is marked by constant returns and perfect competition with unskilled labour its only input; the production function is $Z=A L_{Z}$, where $L_{Z}$ is unskilled labour employed in $Z$ and $A$ is the level of labour-augmenting productivity (assumed to grow exogenously at $\gamma$ ). ${ }^{2}$

Physical capital formation requires only the $\mathrm{X}$ sector composite while human capital formation requires the aggregate composite $C$. Assuming the capital formation sector to be perfectly competitive and subject to constant returns, the laws of motion for human

\footnotetext{
${ }^{2}$ We are aware that services are relatively intensive in human capital. As far as our main results are concerned, the important assumption is that $\mathrm{X}$ is relatively intensive in physical capital. At the cost of additional complication, we could have included human capital in the services sector without altering the key protection-investment-growth link.
} 
and physical capital are:

$$
\dot{H}=\frac{I_{H}}{P}-\delta H, \quad \dot{K}=\frac{I_{K}}{P_{x}}-\delta K
$$

where $I_{H}$ is education spending (a government policy choice financed by lump sum taxation), $I_{K}$ is private investment spending and $\delta$ is the depreciation rate.

The preferences permit two-stage utility maximization. The first stage determines the optimal time path of expenditure; the second determines its temporal allocation. Demand functions from the second stage problem, together with the derived demands from the capital formation sectors, imply that the total expenditure on $\mathrm{Z}$ and a typical $\mathrm{X}$ subsector $\mathrm{i}$ can be expressed as fractions of nominal income:

$$
\begin{gathered}
p_{X i} c_{X i}+\frac{I_{K}+\lambda I_{H}}{N}=\frac{\Lambda Y P}{N}, \quad p_{Z} c_{Z}+(1-\lambda) I_{H}=(1-\Lambda) Y P ; \\
\Lambda \equiv \lambda\left(1-\imath_{K}\right)+\imath_{K}, \quad \imath_{K} \equiv \frac{Y P-E-I_{H}}{Y P}, \quad \iota_{H} \equiv \frac{Y P-E-I_{K}}{Y P}
\end{gathered}
$$

where YP and E are nominal GDP and consumption expenditure, and $t_{1 /}$ and $l_{k}$ are the gross investment rates in human and physical capital.

Given these demand functions, profit maximization in the $\mathrm{X}$ sector implies markup pricing, with markups equal to $1 /\left(1-s_{i}^{j}\right)$ where $s_{i}^{j}$ is share of a typical firm from country $i$ in the market of country $\mathrm{j}^{3}$ Defining relative marginal costs as $Y=\mathrm{m}^{*} \tau / \mathrm{m}, \mathrm{Y}^{*}=\mathrm{m} \tau^{*} / \mathrm{m}^{*}$, where $\mathrm{m}$ and $\mathrm{m}^{*}$ are home and foreign marginal production costs, the Nash equilibrium shares are ${ }^{4}$ :

$$
s_{H}^{H}=\frac{G n^{*}(\Upsilon-1)+1}{n+G n^{*} \Upsilon}, \quad s_{H}^{F}=\frac{(G-1) n^{*}\left(\tau^{\circ}-\Upsilon^{*}\right)+n^{*}\left(1-\Upsilon^{*}\right)+\Upsilon^{*}}{n \Upsilon^{*}+(G-1) n^{*} \tau^{0}+n^{*}}
$$

where $n$ and $n^{*}$ are the equilibrium number of home and foreign firms, and $\tau, \tau^{*}$ and $\tau^{\circ}$ are the home trade barrier factor (i.e., $\tau=1$ under free trade), the typical foreign barrier facing home exports and the typical intra-foreign barriers, respectively.

${ }^{3}$ Equilibrium requires that $\phi$ be such that $n>1$.

4 A detailed exposition of all calculations in the paper can be found in the Calculations Supplement, available from the authors. 
Aggregating the first order conditions of all X-sector firms yields the inverse factor demand functions:

$$
R=p_{x}\left(1-S_{H}^{H}\right) \alpha(H / K)^{1-\alpha}, \quad v=p_{x}\left(1-s_{H}^{H}\right)(1-\alpha)(K / H)^{\alpha}, \quad w=\frac{(1-\Lambda) Y P}{\bar{L}-n N \phi}
$$

When $\mathrm{H}, \mathrm{K}$ and $\mathrm{L}$ equal the current factor stocks, these are full-employment conditions.

Taking 'consumables' as numeraire, real GDP is nominal factor income divided by the perfect Cobb-Douglas price index $\mathrm{P}$. With $\mathrm{Z}$ nontradable, balanced trade means that expenditure equals sales in each sector, so:

$$
Y=\Psi K^{\alpha \lambda} H^{(1-\alpha) \lambda}\left(A L_{Z}\right)^{1-\lambda}
$$

where $Y$ is real GDP and $\Psi$ is the inverse of $\left(\Lambda^{\lambda}(1-\Lambda)^{1 \cdot \lambda}\right) .^{s}$

As Brander and Krugman (1983) showed, as long as the $\tau$ 's are not too high, 'reciprocal dumping' occurs in each of the $\mathrm{N}$ varieties of $\mathrm{X}$.

\section{A. The Equilibrium}

The temporal equilibrium is defined by the Z-sector price and output, the $\mathrm{X}$-sector price and market shares, and the factor prices $w, v$ and $R$. To determine these for the symmetry equilibrium, we use the zero profit and trade balance conditions to find $\mathrm{n}$ and m. These - together with (4), (5), markup pricing in $X$ and marginal cost pricing in $Z$ allow us to determine prices, outputs and market shares.

The intertemporal equilibrium is described by the Euler equation:

$$
\frac{\dot{C}}{C}=r-\rho-\delta ; \quad r=\frac{R}{P_{X}}+\frac{\dot{P}_{X}}{P_{X}}
$$

(2) and the transversality condition. To complete the characterization, note that evolution of $\mathrm{P}_{\mathrm{X}}$ depends upon changes in $\mathrm{H}$ and $\mathrm{K}$. Log total differentiation of the

\footnotetext{
${ }^{5}$ Since $P_{X}=\Lambda Y P / X, p_{z}=(1-\Lambda) Y P / Z, Y=Y P /\left(Y P \Psi^{-1} X^{-\lambda} Z^{-(1-\lambda)}\right)$.
} 
steady-state trade balance condition (with respect to $\mathrm{K}$ and $\mathrm{H}$ ) implies:

$$
\frac{\dot{P}_{X}}{P_{X}}=-(1-\lambda)\left(\alpha \frac{\dot{K}}{K}+(1-\alpha) \frac{\dot{H}}{H}\right)+(1-\lambda) \gamma
$$

This system has no steady state in levels, but applying the standard stationarily-inducing transformation, $\mathrm{c}=\mathrm{C} / \mathrm{AL}_{\mathrm{Z}}, \mathrm{h}=\mathrm{H} / \mathrm{AL}_{\mathrm{Z}}, \mathrm{k}=\mathrm{K} / \mathrm{AL}_{\mathrm{Z}}, \xi_{\mathrm{H}}=\mathrm{I}_{\mathrm{II}} / \mathrm{AL}_{\mathrm{Z}}$, the system becomes:

$$
\frac{\dot{c}}{c}=r-\rho-\gamma-\delta, \quad \frac{\dot{k}}{k}=\frac{y-\xi_{H}-c}{k P_{X}}-(\gamma+\delta), \quad \frac{\dot{h}}{h}=\frac{\xi_{H}}{h}-(\gamma+\delta)
$$

where $\xi_{11}$ is a policy variable (eduction).

The steady-state levels of $c, k$ and $h$ are :

$$
\bar{h}=\frac{\xi_{H}}{\gamma+\delta}, \quad \bar{k}=\frac{\xi_{H}}{\gamma+\delta}\left(\frac{\alpha}{\mu_{H}^{H}(\rho+\gamma+\delta)}\right)^{\frac{1}{1-\alpha}}, \quad \bar{c}=\bar{y}-\xi_{H}-(\gamma+\delta) \bar{k} \bar{P}_{X}
$$

where $\bar{y}=\Psi \bar{k}^{\alpha \lambda} \bar{h}^{(1-\alpha) \lambda}, P_{X}=\Lambda \Psi\left(\bar{k}^{\alpha} \bar{h}^{1-\alpha}\right)^{-(1-\lambda)}$, and $\Lambda$ and $\Psi$ are evaluated at the steady-state investment rate. On the steady-state growth path, $\mathrm{H}, \mathrm{K}, \mathrm{X}, \mathrm{Z}, \mathrm{w}$ and $\mathrm{Y}$ grow at $\gamma$ while $\mathrm{P}, \mathrm{P}_{\mathrm{X}}, \mathrm{P}_{z}, \mathrm{R}, \mathrm{v}, \mathrm{n}$ and the sectoral division of $\mathrm{L}$ are time invariant. Home and foreign protection affect the steady-state levels only through their impacts on the price-marginal cost markup of home firms in the home market.

The system is saddle path stable. In the neighbourhood of the steady state, the saddle path is the eigenvector that corresponds to the negative eigenvalue $\omega$. The explicit solution for local system dynamics:

$$
\left(\begin{array}{l}
k_{t}-\bar{k} \\
c_{t}-\bar{c}
\end{array}\right)=\left(\begin{array}{l}
\left(k_{0}-\bar{k}\right) e^{\omega t} \\
\left(c_{0}-\bar{c}\right) e^{\omega t}
\end{array}\right)
$$

is useful in deriving the estimating equations.

\section{B. Comparative Statics: Trade Liberalization and Capital's Real Return}

Trade policy affects investment via its impact on capital's rate of return. In steadystate this rate of return is $R / P_{X}$, so we investigate the link between home and foreign 
protection, and $R / P_{x}$. With symmetry of varieties, log total differentiation of $K$ 's fullemployment condition yields:

$$
\hat{R}-\hat{P}_{X}=-\hat{\mu}
$$

where $\mu$ is the equilibrium markup $1 /\left(1-\mathrm{S}_{\mathbf{H}}{ }^{\prime \prime}\right)$, and the "^" notation indicates proportional change. Clearly, $R / P_{X}$ rises only when the equilibrium markup falls, that is to say when liberalization has a procompetitive effect. This directs our attention to the determinants of $\hat{\mu}$. Using (5) and $\log$ totally differentiating, we have:

$$
\hat{\mu}=\left(\frac{-n s_{H}^{H}}{n+G n^{*}-1}\right) \hat{n}+\left(\frac{G n^{*} \Upsilon}{n+G n^{*} \Upsilon}\right) \hat{\Upsilon}
$$

The first step is to determine the proportional changes in $n$ and $\Upsilon$ with respect to $\tau$ and $\tau^{*}$. Using standard comparative-static techniques, it can be shown that (see the calculations supplement) that:

$$
\hat{\Upsilon} / \hat{\tau}>0, . \quad \hat{\Upsilon} / \hat{\tau}^{*}>0, \hat{n} / \hat{\tau}^{*}<0, \hat{n} / \hat{\tau}>0
$$

Intuition for these results is as follows. $\Upsilon$ (the relative competitiveness of home firms in the home market) is obviously boosted by home protection (that's why they call it protection). Foreign barriers boost $\Upsilon$ via a negative terms of trade effect that makes home resources cheaper than foreign resources. The result that $\hat{n} / \hat{\tau}^{*}$ is negative stems from the fact that foreign protection shifts expenditure away from home firms, thereby reducing $R$ and inducing exit. The positive impact of $\tau$ on $n$ comes from the competitiveness gain.

Given (13) and (14), we cannot sign the impact on the markup in general, but in the neighbourhood of symmetric free trade, $\Upsilon=1, m=m^{*}, n=n^{*}$ and $s_{11}{ }^{\prime \prime}$ equals $1 /(n(G+1))$, so:

$$
\frac{\hat{\mu}}{\hat{\tau}}=\left(\frac{-1}{(G+1)(n+G n-1)}\right) \frac{\hat{n}}{\hat{\tau}}+\left(\frac{G}{G+1}\right) \frac{\hat{\Upsilon}}{\hat{\tau}}
$$

The small-country assumption implies that $1 /(1+G)$ is very small, so the first term is negligible while the second remains positive and finite. Thus, raising $\tau$ has an 
anticompetitive effect and this lowers the $R / P_{X}$. Since $\hat{n} / \hat{\tau}^{*}$ is negative, foreign protection unambiguously raises the markup.

\section{Empirical Implementation}

\section{A. Derivation of Estimating Equations}

Since data on effective units of labour are unavailable, we specify the model in terms of per capita growth. Log totally differentiating of the GDP function, taking account of exogenous technological progress and population growth $\eta$, we have:

$$
\frac{\dot{y}}{y}=\gamma(1-\lambda)-\lambda \frac{\dot{L}}{L}+\left(\frac{\alpha \lambda}{K / Y}\right) \frac{\dot{K}}{Y}+\left(\frac{(1-\alpha) \lambda}{H / A L_{Z}}\right) \xi_{H}-(1-\alpha) \lambda \delta
$$

In the model technical progress is steady, however many researchcrs have observed a 'catch-up' factor. That is, countries' technological progress seems related to the gap between their per capita incomes and that of the leader (the US). Furthermore, it is likely that the level of human capital influences a nation's ability to implement new know-how. To allow for these factors (which are outside the scope of our formal model), we assume that the growth rate of $A$ for country $j$ is:

$$
\gamma_{j}=\xi_{A}+\xi_{c}\left(\left(\frac{Y}{L}\right)_{U S}-\left(\frac{Y}{L}\right)_{j}\right)+\chi h_{0}+\epsilon_{1 j}
$$

where $\varepsilon_{\mathrm{j}}$ is the country-specific idiosyncratic shock.

The only endogenous variable in the growth equation (recall that education is a policy choice) is physical capital accumulation. The law of motion for $k$ governs investment, however this is a nonlinear function of the state variables. To derive an estimating equation for this variable, we take a first-order Taylor expansion around the steady state assuming that the investment rate is approximately constant. Plugging in the equilibrium $P_{X}$, solving the differential equation for $h$ and using the fact that $k$ approaches the steady state along the eigenvector corresponding to the negative 
eigenvalue, we have :

$$
\frac{\dot{k}_{T}}{k_{T}}=(1-\alpha)(\gamma+\delta) e^{\omega T}\left(\frac{\bar{k}-k_{0}}{\bar{k}}\right)+(1-\alpha)(\gamma+\delta) e^{-(\gamma+\delta) T}\left(\frac{h_{0}-\bar{h}}{\bar{h}}\right)
$$

Using a log linearization, this can be rewritten as:

$$
\frac{\dot{k}_{T}}{k_{T}}=b_{1}\left(\ln \bar{k}-\ln k_{0}\right)+b_{2}\left(\ln h_{0}-\ln \bar{h}\right)
$$

where $b_{1}$ and $b_{2}$ equal $(1-\alpha)(\gamma+\delta) e^{\omega T}$ and $(1-\alpha)(\gamma+\delta) e^{-(\gamma+\delta) T}$ respectively.

The next step is to evaluate the variables in terms of observables. To this end, we note that:

$$
\ln \bar{k}=\ln \bar{h}+\frac{1}{1-\alpha} \ln \bar{\mu}^{-1}+\frac{1}{1-\alpha} \ln \left(\frac{\alpha}{\rho+\gamma+\delta}\right)
$$

Recalling that $\ln \left(\mu^{-1}\right)$ equals $\ln \left(1-\mathrm{s}_{\| \prime}{ }^{\mathrm{H}}\right)$ and taking a first-order Taylor expansion around the symmetric, free trade point, we get:

$$
\ln \left(\mu^{-1}\right)=\ln \left(1-s^{F T}\right)-\left(\frac{M^{F T}}{Y}\right)\left(\frac{1}{\Lambda} \frac{\partial \Upsilon}{\partial \tau}\right)(\tau-1)-\left(\frac{M}{Y}\right)\left(\frac{1}{\Lambda} \frac{\partial \Upsilon}{\partial \tau^{*}}\right)\left(\tau^{*}-1\right)
$$

where $1-\mathrm{s}{ }^{\mathrm{FT}}$ and $\mathrm{M}^{\mathrm{FT}}$ are the inverse of the markup and the level of imports with free trade. In deriving this, we have used the fact that in the neighbourhood of free trade, the partial of $\mu$ with respect to $n$ is approximately zero for a small country.

Using the formula for the steady-state $h$, and substituting in the intermediate results from above, we can write the proportional growth of $k$ as:

$$
\kappa-b_{1} \ln k_{0}+b_{2} \ln h_{0}+\left(b_{1}-b_{2}\right) \ln \xi_{H}-\left(\frac{M^{F T}}{Y}\right)\left(\frac{b_{1}}{\Lambda(1-\alpha)}\right)\left(\frac{\partial \Upsilon}{\partial \tau}(\tau-1)+\frac{\partial \Upsilon}{\partial \tau^{*}}\left(\tau^{*}-1\right)\right)
$$

where $\kappa$ is a constant. Finally, assuming the capital-output ratio to be approximately constant near steady state, we get the estimating equation for the investment to GDP 
ratio as:

$$
\left(\frac{I}{Y}\right)_{j}=\beta_{21}-\beta_{22} \ln \left(\frac{Y}{L}\right)_{j 0}+\beta_{23} \ln \xi_{H_{j}}+\beta_{24} \ln h_{j 0}-\beta_{25} O_{j} \tau^{*}-\beta_{26} O_{j} \tau+\epsilon_{2 j}
$$

where $O_{j}$ is the import-to-GDP ratio that country $j$ would have under free trade.

Summarizing, the two-equation system to be estimated is:

$$
\begin{aligned}
& \left(\frac{\dot{Y}}{Y}\right)_{j}=\beta_{11}-\beta_{12}\left(\frac{Y}{L}\right)_{j 0}-\beta_{13} \eta_{j}+\beta_{14}\left(\frac{\dot{K}}{Y}\right)_{j}+\beta_{15}\left(\xi_{H}\right)_{j}+\beta_{16} h_{j o}+\epsilon_{1 j} \\
& \left(\frac{I}{Y}\right)_{j}=\beta_{21}-\beta_{22} \ln \left(\frac{Y}{L}\right)_{j 0}+\beta_{23} \ln \xi_{H_{j}}+\beta_{24} \ln h_{j 0}-\beta_{25} O_{j} \tau^{*}-\beta_{25} O_{j} \tau+\epsilon_{2 j}
\end{aligned}
$$

where all $\beta$ s are positive.

Given the complexity of the derivation, we provide intuition for predicted signs of the $\beta$ 's. The impact of the initial Y/L level is negative, reflecting a catch-up factor related to the initial technology gap. The motivations for the signs of all other $\beta_{1}$ 's are well-know. ${ }^{6}$ In the investment rate equation, the initial $\mathrm{Y} / \mathrm{L}$ level should also enter negatively since it acts as a proxy for the initial level of $\mathrm{k}$. The $\mathrm{H}$ investment rate, $\xi_{\| 1}$, should enter positively since it is a determinant of the steady-state $h$ and this boosts the steady-state $k$. For any given level of $Y / L$, a higher steady-state $k$ implies a higher investment to GDP ratio. The trade variables require more explanation. Our derivations show that the home and foreign tariff need to be multiplied by the country's openness under free trade. Heuristically, this is because both domestic and foreign protection should have more important economic consequences in countries that are 'naturally' open (say Hong Kong), than in countries that are 'naturally' closed (say the US). This point was first made by Lee (1993).

\section{B. Data Issues}

Most variables correspond to obvious data series (see data appendix for details). Some variables, however, involve less obvious choices. A wide range of measures for

\footnotetext{
${ }^{6}$ See Mankiw, Romer and Weil for a recent formulation.
} 
the rate of investment in human capital variable (viz. $\xi_{H}$ ) exist. We experimented with several enrolment data series - e.g. secondary school enrolment ratios of males, females and total, primary school enrolment ratios of males, females and total and the sum of these. We found that secondary enrolment rates for males proved most satisfactory. In our model, the rate of human capital investment is the choice of the government and so exogenous. It is reasonable, however, to posit that $\xi_{H}$ is affected by endogenous variables such as per capita income. To allow for this we instrument for the average human capital investment rate $\xi_{\mathrm{H}}$ with a predetermined variable, i.e. the enrolment rate at the beginning of the time period sample (the point estimates were little changed by this but the $\mathrm{H}$ investment variable was more significant in the investment equation). For the initial stock of human capital we use secondary achievement rates at the beginning of the time period sample.

The trade barrier variables also involved some discretion. For $\tau$, the closest corresponding variable was constructed by Lee and Swaigel (1992) and can be found in the widely-available Barro-Lee dataset as OWTI. This is an import-weighted average of ad valorem import charges on consumer, intermediate and capital goods using tariffs rates at the most detailed level of the Customs Cooperation Council Nomenclature. They are collated by the United Nations from national sources. The natural openness factors, $\mathrm{O}_{\mathrm{j}}$, are taken from Lee (1993) and are the fitted values of an openness regression that he ran on Sunmers-Heston import to GDP ratios. ' The use of fitted values has the merit of avoiding the usual downward bias that comes from using actual import shares.

The foreign trade barriers variable for a particular country is the trade-weighted average of the OWTIs for each country's top five export markets. To reduce the bias that protection introduces to the export weights, we do not use data on actual exports. Instead, the weights employed are the fitted values from a gravity model estimated by Baldwin (1994). That is, using the coefficients reported in Baldwin (1994), we determine the 'normal' trade flows between each country in our sample and its five most

\footnotetext{
${ }^{7}$ The regressors were a constant, the log of national land area, the distance from the national capital of the world's top 20 exporters, and two proxies for trade barriers - the Lee-Swaigel tariff variable and the black market premium. The fitted values for free trade openness are generated setting the proxies for trade barricrs to zero.
} 
important trading partners. The weighted average of foreign barriers is then multiplied by FREEOP as with the domestic trade barrier variable. The same procedure is undertaken with respect to several other trade barrier proxies. A final note concerns the treatment of intra-Western European trade. Since tariffs among EU and EFTA nations have been zero since 1974 (among EU members since 1968 and among EFTA members since 1969), we impose a zero tariff rate on bilateral trade flows among EU and EFTA nations. Although many of the top five partners of the EU and EFTA nations are other EU and EFTA nations, the procedure had little effect on the results. In an earlier version of this paper, we did not adopt this strategy and the main results were unchanged from those presented below.

The sample-selection criteria for the countries included in our sample is suggested by the nature of the model. Our theoretical model clearly corresponds to countries that are primarily engaged in intra-industry trade in manufactured goods. To select such countries, we use World Bank data on the structure of exports. ${ }^{8}$ First we aggregated export conmodities into three broad groups: 1) fuel, minerals and metals, 2) other primary commodities and 3) manufactures, which consists of machinery and transport equipment, other manufactures, and textiles and clothing. If a country's manufactures share was the highest of its three shares, we included the country in our sanple. This selection was done for two base years, 1965 and 1989 (see data appendix). The 1965based sample is quite small consisting of only 20 countries. The 1989 sample contains 39 countries. Note that not all of the OECD countries qualify as manufacture exporters.

Given the assumptions of our theoretical model, the investment ratio is the only endogenous variable in the growth equation; All other variables are predetermined like initial $\mathrm{Y} / \mathrm{L}$ or policy variables assumed to be exogenously chosen. All independent variables in the investment equation are predetermined or exogenously chosen. We estimate the system of equations (24) with three-stage least squares using all variables except the investment share and per capita growth as instruments.

\footnotetext{
${ }^{8}$ Specifically, Table 16 "Structure of Merchandise Exports" of the World Development Report, 1991.
} 


\section{Results}

Presentation of the estimates are organized around our two basic results. The first concerns the impact of trade barriers on investment and growth. The second concerns one particular mechanism through which trade affects growth.

\section{A. Anti-Growth Effects of Domestic and Foreign Trade Barriers}

Table 2 shows the results for our preferred sample and specification, namely the sample of countries that were manufacture exporters in 1989 and the empirical implementation of the theoretical model given by (24). All of the point estimates in the growth equation that are significant are of the sign predicted by the theoretical model. The estimated coefficient on $(\mathrm{Y} / \mathrm{L})_{0}$ is negative and highly significant, suggesting that a technology catch-up factor is in operation. The small magnitude of the point estimate reflects the mean of the dependent variable. Population growth is insignificant as is often the case in cross-country growth regressions. The estimate for the human capital investment is negative contrary to the prediction of the model, but insignificant. The initial level of $\mathrm{H}$ has a positive sign as predicted, and it is almost significant. The point estimate for physical capital formation is 0.24 and is significant at all reasonable levels of confidence. The R-square is 0.54 , which is high given that we are working with cross-section data.

Results for the investment equation are also quite good. The $(\mathrm{Y} / \mathrm{L})_{0}$ and population growth variables have negative coefficients as predicted but are both statistically insignificantly different from zero. Initial $\mathrm{H}$ has a negative coefficient contrary to the model's prediction, but it is insignificant. The estimated parameter for human capital formation variable is significant and positive. Note that the R-square is a remarkable 0.74 .

The point estimate for the domestic and foreign trade barrier variables are quite interesting. Both coefficients are negative and highly significant, suggesting that both domestic and foreign protection discourage investment. The negative sign on home barriers has been found by many researchers, but our theoretical model permits us to interpret this result. Domestic barriers raise the rental rate on capital (because the 
import competing industry is capital-intensive) but also raise the cost of new capital since manufactured goods are used as an input in capital formation. The former boost the rate of return on physical capital formation while the latter reduces it. Our empirical results suggest that the anti-investment aspects of domestic protection outweigh the proinvestment effects.

The estimated coefficient on foreign barriers is also significant and negative. This finding has not, to our knowledge, been reported in the literature. Note that although our results suggest that foreign trade barriers - as well as domestic trade barriers - harm domestic investment and growth, the point estimates indicate that domestic protection is more harmful to investment and growth than foreign trade barriers.

Alternate Data Samples The first column of Table 3 reproduces the results for our preferred specification and data sample. The other columns shows the estimates of the preferred specification on different samples of countries. The second column shows the results for the sample of countries that were manufacture exporters in 1965 (as opposed to 1989 which was the selection year for the first column sample). The 1965-based sample is much smaller containing only 20 countries as opposed to 39 countries in the colunın-one sample. Comparison of the two columns shows that the point estimates are very similar. From the point of view of our main results, the principle difference is that foreign barriers are insignificant in the smaller sample although the point estimate in the 1965-based sample is also negative. ${ }^{9}$ The colunn-2 estimate for domestic barriers is negative, significant and approximately the same size as the colunın-1 estimate.

The third column presents results for a large data set that include all countries for which we had complete data without regard to their commodity trade pattern. ${ }^{10}$ The column-3 results broadly confirm the column- 1 findings. All variables that are insignificant in column-1 are also insignificant in column 3. All the colunn-1 variables that are significant are also significant. In particular domestic barriers continue to show a highly significant and negative impact on the investment share. The point estimate of the foreign trade barrier variable coefficient is negative and significant at the $5 \%$ level.

\footnotetext{
${ }^{9}$ The 1965-based results has the problem that investment in human capital is estimated to have a negative and significant impact on growth.

${ }^{10}$ Specifically the Barro and Sala-i-Martin (1995) that includes 97 countries of which 75 have complete data.
} 
The last column shows the results from estimating the preferred specification on a data set that includes only countries who mainly export primary goods other than manufactures. "In particular the sample is of those countries that were primary commodity exporters in 1965 . Our model, unfortunately, cannot formally allow for countries that are exporters of primary goods since all trade is intra-industry trade. Informally, however, domestic trade barriers should continue to hinder investment in countries that export primary goods by raising the cost of new capital. By contrast, foreign barriers should have little effect on investment in these countries for two reasons. First, if their exports are not capital-intensive, foreign barriers will not depress their rental rates. This leaves only the weak general equilibrium effect. Second, our trade barrier variable is an average rate weighted by countries' own import pattern. This poses a problem since most primary goods - apart from temperate agricultural goods are dutied at a systematically lower rate in developed countries than general imports. Consequently, our proxies will systematically overestimate the true foreign barriers faced by primary good exporters.

The column-4 estimates are in line with this informal reasoning. Namely, the domestic barriers continue to be significant and negative, but foreign barriers are insignificant. Note that the point estimate on domestic barricrs is fairly robust to sample changes in that it remains between -1.0 and -1.3 in all samples.

Reduced Form Estimates Given our model, it is possible to derive a reduced-form growth equation and derive an estimating equation that is valid near the steady state. The derivation procedure is similar to that of Mankiw, Romer and Weil (1992) and Lee (1993), so we do not reproduce it here. An important difference between the MankiwRomer-Weil specification and ours is that the investment rate is an endogenous variable in the neoclassical model - not an exogenous variable as in the Solow model on which Mankiw-Romer-Weil base their theory.

The results, presented in Table 4, show that the domestic trade variable has the expected sign (negative) and is significant in all samples. The foreign trade variable is not significant any sample, although all point estimates are negative.

\footnotetext{
"The country-selection procedure is similar to the selection for manufactures exports except we select countries for which the Other Primary Goods (i.e. non oil and minerals) export share was the highest of the three shares.
} 
Alterative Specifications To check for the possibility that our theoretical model is misspecified and our results are due to a correlation between the included and omitted variables, we re-run the regression including a number of growth correlates that researchers have put into growth regressions based on ad hoc reasoning. In particular we try three of the growth correlates used in Barro (1991), namely REVCOUP (a measure of the number of revolutions and coup d'états), AVGGOVCONS (the average share of government consumption in GDP) and AVGFERT6084 (the average fertility rate from 1960 to 1984). Table 5 shows the results.

In the first column of the table, the favoured specification is reproduced for comparison. The next three pairs of columns show the point estimates and t-statistics for regressions that include extra growth correlates in both the growth and investment equations. As always estimation is by three-stage least-squares. The domestic trade barrier variable remains negative and significant in all regressions. The point estimates are changed somewhat but never more than two standard errors from the original point estimate (using the original standard error).

The foreign trade barrier variable is more fragile to the inclusion of these extra variables in that one of the point estimates is positive. However, all significant estimates are negative.

Alternative Trade Barrier Proxies The tariff variable developed by Lee and Swaigel (1992) is our preferred trade barrier proxy since it most closely matches the type of barriers in the model. Moreover, it is available for a wide range of countries, although not on a time-series basis. It is worthwhile, however, investigating the impact of estimating our specification using alternative trade barrier proxies. Table 6 presents some other trade barrier proxies. The first column shows the results for the black market premium. This proxy has the obvious drawbacks that it does not directly measure import restrictions and it is zero for many of the countries in the 1989-based manufacture sample. Nonetheless, it produces a significant and negative estimate for domestic barriers, although the foreign barriers variable is insignificant. This latter result is entirely expected since the main trading partners of virtually all manufacture exporters are a handful of large, rich countries such as the US, Germany, Japan, France, etc. and these countries do not have positive black market premiums.

The second column show results for an indicator of quantitative restrictions (QRs). 
This indicator is seriously flawed in that it does not weight QRs by the amount of trade affected or the restrictiveness of the QR. The estimated coefficients on the trade barrier variables are both negative, but insignificant. The results for the Leamer (1988) measure of openness are presented in the third column. Again domestic and foreign openness are found to boost investment but neither are statistically different from zero. The next column show results for Leamer's measure of "intervention" (the sum of the absolute values of residuals from his net-trade Heckscher-Ohlin model). Both the domestic and foreign barriers are positive, and home openness is significant. The relationship between Leamer's measure and trade protection is ill-defined. For instance if the average country is protectionist, then both extraordinarily open and extraordinarily closed countries would have large residuals. Other researchers have found mixed results for this proxy. ${ }^{12}$

The last two columns shows results for unadjusted export to GDP and import to GDP ratios. Our estimates show that domestic openness has a positive and close to significant effect on the investment share. Foreign openness is insignificant, but of the expected sign.

Table 7 shows the results for the same specification and estimatator with three trade proxies from the De Long and Summers (1991) paper. The first two are based surveys of business leaders from the World Competitiveness Report. The last measure comes from the residuals of a gravity model estimated by Barbone. None of these exist for a large sample of countries (we are working with 7 independent variables, so a sample of 20 is small) and none of them yield satisfactory results. For instance, for the first two measures, nothing is significant in the investment equations.

\section{B. Trade-Induced Investment-led Growth or Export-led Growth?}

The second main prediction of our theoretical model - and indeed of virtually any neoclassical growth model - is that trade does not affect output growth directly. Trade affects growth via its impact on investment. This is almost a tautology when one

12 Levine and Renelt find this to be robustly and positively related to investment. Edwards (1992) found it to be negatively correlated with growth. 
considers all types of investment, e.g. investment in human capital, physical capital and knowledge capital (technology). Neoclassical models, however, treat technological progress as exogenous, so the level of trade barriers should not affect output growth in an equation that includes investment in human and physical capital. Clearly we do not believe that technological progress truly is exogenous; Nor do we believe that trade barriers have nothing to do with technical progress. The test here is about how important trade barriers are in explaining growth controlling for their impact on the investment rate in physical capital.

To estimate the direct impact of trade on growth, controlling for its indirect impact via investment, we re-estimate the system including the trade variables in the growth equation and investment equations. If the predictions of the model are correct, the trade variables should be insignificant in the growth equation but significant in the investment equation.

The results in Table 8 broadly confirm this prediction. Both trade barrier variables have $t$-statistics less than 2 in all of the samples except the small manufactures-1965 sample. ${ }^{13}$ Nonetheless, domestic trade barriers continue to have a negative and significant effect on investment in all samples. Foreign barriers are found to hinder investment in our preferred sample and in the largest sample. These finding is in the spirit of the results that Levine and Renelt (1992) obtain using single-equation ordinary least squares estimation.

The point estimates on the trade variables in the per capita growth regression essentially measure the impact of trade openness on total factor productivity growth since the contribution of physical and human capital investment are controlled for directly. Although trade variables are significant in only one small sample, we do not view this as conclusive evidence against the hypothesis that trade can affect the rate of technology progress. Coe and Helpman (1995) for instance find that bilateral trade does affect the rate of technology progress. In this light, our results are best interpreted as saying that this sort of effect is not strong enough to show up in such a broad crosssection data set. For instance, in many growth models (e.g. Helpman and Grossman (1991)), the rate of knowledge accumulation is proportional to the rate of physical

\footnotetext{
${ }^{13}$ In this latter sample, domestic barriers have a negative direct impact on growth.
} 
capital formation. Thus with physical capital accumulation linearly related to investment, the estimated coefficient on the investment variable may be picking the influence of the omitted knowledge creation variable. In other words, it may be that there is such a close correlation between $\mathrm{K}$ investment and technological progress that it is impossible to disentangle the impact of trade on innovation with cross-section data.

\section{Summary and Concluding Remarks}

This paper uses a novel theoretical model to establish a link between trade policy and investment-led growth. Estimating equations are derived from the model and estimated with three stage least squares. We find that domestic protection depresses investment and thereby slows growth. Foreign trade barriers also lower domestic investment, but the anti-investment effect is weaker and is less robust to sample and specification changes.

The theoretical model assumes each country has a traded and nontraded goods sector with the traded goods sector being relative capital intensive. Additionally, we assume that trade goods are an intermediate input into the production of new capital. In this model, domestic protection creates conflicting influences on the steady-state capitallabour ratio and thereby on the steady-state investment-to-GDP ratio. The StolperSamuelson theorem implies that domestic protection raises capital's rental rate. This tends to raise the steady-state capital-labour and investment-to-GDP ratios. The protection, however, also raises the marginal cost of producing new capital and this tends to lower the ratios. Domestic protection's net impact is ambiguous in general, but can be shown to be negative in the neighbourhood of free trade. Foreign protection unambiguously lowers the investment rate, since it lower the rental rate without altering the marginal cost of producing capital.

In future empirical research, it should be possible to delve more deeply into thc impact of protection on the cost of new capital goods. One approach would be to use the input-output matrix for the capital goods sectors to create a more targeted measurc of investment-deterring protection. 


\section{$\underline{\text { References }}$}

Baldwin, Richard E. (1994) Towards an Integrated Europe, CEPR, London.

Barro, R. (1991), "Economic growth in a cross-section of countries", Quarterly Journal of Economics, CVI, 2, pp 407-443.

Brander, J and P. Krugman, (1983) "A 'reciprocal dumping' Model of International Trade", Journal of Intentional Economics, 15, pp. 313-323.

Cairncross, A. (1962) Factors in Economic Development, Allen \& Unwin, London. Coe, D.T. and Helpman, E. (1995) "International R\&D Spillovers" European Economic Review, 39, 5, pp 859-887.

De Long and L. Summers (1991) "Equipment investment and economic growth" Quarterly Journal of Economics, pp 445-502.

Edwards, S. (1993) "Openness, Trade liberalization and growth in developing countries" Journal of economic literature, XXXI, pp 1358-1393.

Edwards, S. (1992) "Trade orientation, distortions and growth in developing countries, Journal of development economics, 39, 1, pp. 31-57

Harrison, A. (1995) "Openness and Growth: A time-series, cross-country analysis for developing countries," forthcoming, Journal of Development Economics.

Harrison, A. (1995) "Openness and Growth: A time-series, cross-country analysis for developing countries," forthcoming, Journal of Development Economics.

Leamer, E. (1988) "Measures of Openness" in R. Baldwin (ed) Trade policv issues and empirical analysis, Chicago University Press for NBER.

Lee, JW (1994) "Capital goods imports and long-run growth," NBER paper No.4725. Lee, JW (1993) "International trade, distortions and long-run growth," IMF Staff Papers, 40,2, pp. 299-328.

Lee, JW and P. Swaigel (1992) "Measuring Trade Distortion," mimeo, Harvard University.

Levine R. and D. Renelt (1992) "A sensitivity analysis of cross-country growth regressions", American economic review, 82,4, pp 942-963.

Mankiw, G., Romer, D. and Weil, P, "A contribution to the empirics of economic growth," Quarterly Journal of Economics, May, pp 407-437.

Grossman, G. and Helpman, E. (1991), Innovation and Growth in the World Economy, MIT Press, Cambridge USA. 
Table 1

\section{Capital intensity for different industries, 1987}

\begin{tabular}{|c|c|c|c|c|c|c|c|c|c|}
\hline & & \multicolumn{2}{|l|}{ Japan } & \multicolumn{3}{|c|}{ UK } & \multirow{3}{*}{$\begin{array}{r}\text { Sector's } \\
\% \text { of } \\
\text { GDP }\end{array}$} \\
\hline & \multirow[b]{2}{*}{ Capital } & Capital & \multirow{2}{*}{$\begin{array}{r}\text { Sector's } \\
\% \text { of } \\
\text { GDP }\end{array}$} & \multicolumn{2}{|c|}{ Value added share } & \multirow{2}{*}{$\begin{array}{r}\text { Sector's } \\
\% \text { of } \\
\text { GDP }\end{array}$} & \multicolumn{2}{|c|}{$\frac{\text { Value added share }}{\text { Capital }}$} & \\
\hline & & $\begin{array}{l}\text { Capital } \\
\text { +profit }\end{array}$ & & Capital & $\begin{array}{l}\text { Capital } \\
\text { +profit }\end{array}$ & & Capital & $\begin{array}{l}\text { Capital } \\
+ \text { profit }\end{array}$ & \\
\hline Agriculture & $17 \%$ & $88 \%$ & $2 \%$ & $24 \%$ & $74 \%$ & $3 \%$ & $22 \%$ & $69 \%$ & $2 \%$ \\
\hline Mining & $46 \%$ & $55 \%$ & $2 \%$ & $23 \%$ & $75 \%$ & $0 \%$ & $25 \%$ & $78 \%$ & $4 \%$ \\
\hline Manufacturing & $12 \%$ & $26 \%$ & $19 \%$ & $15 \%$ & $39 \%$ & $28 \%$ & $11 \%$ & $32 \%$ & $23 \%$ \\
\hline $\begin{array}{l}\text { Financial Services } \\
\text { Non Tradables }\end{array}$ & $14 \%$ & $54 \%$ & $25 \%$ & $20 \%$ & $72 \%$ & $15 \%$ & $16 \%$ & $62 \%$ & $22 \%$ \\
\hline Construction & $7 \%$ & $34 \%$ & $5 \%$ & $13 \%$ & $39 \%$ & $8 \%$ & $3 \%$ & $50 \%$ & $6 \%$ \\
\hline Wholesale\& Retail & $8 \%$ & $25 \%$ & $17 \%$ & $8 \%$ & $35 \%$ & $13 \%$ & $7 \%$ & $36 \%$ & $13 \%$ \\
\hline $\begin{array}{l}\text { Transport, Storage } \\
\text { \& Communications }\end{array}$ & $19 \%$ & $39 \%$ & $6 \%$ & $17 \%$ & $27 \%$ & $6 \%$ & $22 \%$ & $37 \%$ & $7 \%$ \\
\hline Utilities & $26 \%$ & $57 \%$ & $3 \%$ & $25 \%$ & $66 \%$ & $3 \%$ & $33 \%$ & $57 \%$ & $3 \%$ \\
\hline Other Private Services & $6 \%$ & $25 \%$ & $10 \%$ & $9 \%$ & $40 \%$ & $14 \%$ & $5 \%$ & $41 \%$ & $5 \%$ \\
\hline Government Services & $10 \%$ & $10 \%$ & $12 \%$ & $8 \%$ & $8 \%$ & $8 \%$ & $5 \%$ & $5 \%$ & $14 \%$ \\
\hline Other Producers & $0 \%$ & $0 \%$ & $0 \%$ & $0 \%$ & $0 \%$ & $2 \%$ & $0 \%$ & $0 \%$ & $2 \%$ \\
\hline Economy Average & $12 \%$ & $35 \%$ & & $14 \%$ & $42 \%$ & & $12 \%$ & $40 \%$ & \\
\hline
\end{tabular}

Source: OECD Detailed National Accounts, Tables 12,13

Averages by Sector Groups

\footnotetext{
$\begin{array}{lll}\text { Tradables } & 7 \% & 21 \%\end{array}$

(ag.,mining,manf,fin.)

$\begin{array}{lcc}\text { Non Tradables } & 5 \% & 13 \% \\ \text { (elec,construction, whole.\&retail,priv.services }\end{array}$

govt services, other producers)
}

Japan

ded share

Mining 
Table 2: Results for preferred sample and specification.

\begin{tabular}{|c|c|c|c|c|c|}
\hline \multicolumn{6}{|c|}{$\begin{array}{l}\text { (Sample is Manufactures Exporters in } 1989 \text {, } \\
\text { number of observations }=39 \text { ) }\end{array}$} \\
\hline \multicolumn{3}{|c|}{ Growth Equation } & \multicolumn{3}{|c|}{ Investment Equation } \\
\hline & coeff. & $t$-stat & & coeff. & t-stat \\
\hline Constant & -0.02 & -1.5 & Constant & 0.49 & 3.4 \\
\hline $\begin{array}{l}\text { Initial } \\
Y / L\end{array}$ & $-4 e-06$ & -3.4 & $\log _{Y / L}$ Initial & -0.02 & -1.1 \\
\hline Pop.Growth & 0.29 & 0.9 & $\log$ Pop. Growth & $-4 e-03$ & -0.3 \\
\hline $\begin{array}{l}\text { H } \\
\text { Investment }\end{array}$ & -0.01 & -0.8 & $\begin{array}{l}\log \mathrm{H} \\
\text { Investment }\end{array}$ & 0.08 & 4.9 \\
\hline Initial $\mathrm{H}$ & $4 e-04$ & 1.8 & $\log$ Initial $\mathrm{H}$ & $-2 e-03$ & -0.2 \\
\hline \multirow[t]{2}{*}{$\begin{array}{l}\mathrm{K} \\
\text { Investment }\end{array}$} & 0.24 & 6.2 & $\begin{array}{l}\text { Domestic } \\
\text { Barriers }\end{array}$ & -1.05 & -3.8 \\
\hline & & & $\begin{array}{l}\text { Foreign } \\
\text { Barriers }\end{array}$ & -0.82 & -2.0 \\
\hline$R * \star 2$ & & 0.54 & $R \star \star 2$ & & 0.74 \\
\hline
\end{tabular}

Three-stage least squares is employed. The sample includes only nations that were manufacture exporters in 1989 (see data appendix). The estimated system is (see section 4 for the derivation):

$$
\begin{gathered}
\dot{Y} / Y=\beta_{11}-\beta_{12}\left(\frac{Y}{L}\right)_{j 0}-\beta_{13} \eta_{j}+\beta_{14}\left(\frac{\dot{K}}{Y}\right)_{j}+\beta_{15}\left(\xi_{H}\right)_{j}+\epsilon_{1 j} \\
I / Y=\beta_{21}-\beta_{22} \ln \left(\frac{Y}{L}\right)_{j 0}+\beta_{23} \ln \xi_{H}+\beta_{24} \ln h_{j 0}-\beta_{25} O_{j} \tau^{*}-\beta_{25} O_{j} \tau+\epsilon_{2 j}
\end{gathered}
$$

where $\mathrm{Y} / \mathrm{L}_{0}$ is real per capita income in 1960 (GDPSH560), $\eta$ is average population growth (GPO6084), $\xi_{H}$ is the 1960 secondary school enrolment rate (SM60), ho is the secondary school attainment rate (SEC60), physical capital formation is the average investment to GDP ratio (INVSH6089) from 1960 to 1989. In the investment equation the above variables are in logs while the domestic and foreign trade barriers are HOM4 and FOR4GE respectively. HOM4 is FREEOP times OWTI, and FOR4GE is FREEOP times OWTIGE, where OWTIGE is the OWTI's of a country's five most important export markets weighted by the fitted export shares calculated with a gravity model. 
Table 3: Preferred Specification with Alternate Data Samples.

\begin{tabular}{|c|c|c|c|c|c|c|c|c|}
\hline & \multicolumn{8}{|c|}{ Samples } \\
\hline & \multicolumn{2}{|c|}{$\begin{array}{l}\text { Manufactures } \\
\text { Exporters } \\
\text { In } 1989\end{array}$} & \multicolumn{2}{|c|}{$\begin{array}{l}\text { Manufactures } \\
\text { Exporters } \\
\text { In } 1965 \\
\end{array}$} & \multicolumn{2}{|c|}{ Barro-Lee } & \multicolumn{2}{|c|}{$\begin{array}{l}\text { Primary Goods } \\
\text { Exporters } \\
\text { in } 1965\end{array}$} \\
\hline & \multicolumn{2}{|c|}{$(\#$ obs. $=39)$} & \multicolumn{2}{|c|}{$\#$ obs. $=20$} & \multicolumn{2}{|c|}{$(\#$ obs. =75) } & \multicolumn{2}{|c|}{$(\#$ obs. $=40)$} \\
\hline \multicolumn{9}{|l|}{ Growth Equation } \\
\hline & coeff & $\begin{array}{c}t- \\
\text { stat }\end{array}$ & coeff. & $\begin{array}{c}t- \\
\text { stat }\end{array}$ & CoefE. & $\begin{array}{c}t- \\
\text { stat }\end{array}$ & coefE. & $\begin{array}{c}t- \\
\text { stat }\end{array}$ \\
\hline Constant & -0.02 & -1.5 & -0.03 & -2.1 & $1 e-03$ & 0.1 & $-8 e-04$ & -0.1 \\
\hline Initial $Y / L$ & $-4 e-06$ & -3.4 & $-4 e-06$ & -3.4 & $-4 e-06$ & -4.0 & $-6 e-06$ & -2.6 \\
\hline Pop.Growth & 0.29 & 0.9 & 0.74 & 1.7 & -0.21 & -0.9 & -0.08 & -0.2 \\
\hline$H$ Investment & -0.01 & -0.8 & -0.03 & -2.0 & 0.01 & 0.4 & 0.02 & 0.9 \\
\hline Initial $\mathrm{H}$ & $4 e-04$ & 1.8 & $7 e-04$ & 2.7 & $3 e-04$ & 1.6 & $8 e-05$ & 0.3 \\
\hline $\mathrm{K}$ Investment & 0.24 & 6.2 & 0.29 & 7.1 & 0.15 & 2.9 & 0.15 & 3.2 \\
\hline $\mathrm{R} * * 2$ & \multicolumn{2}{|r|}{0.54} & \multicolumn{2}{|r|}{0.52} & \multicolumn{2}{|r|}{0.44} & \multicolumn{2}{|r|}{0.60} \\
\hline \multicolumn{9}{|c|}{ Investment Equation } \\
\hline & coeff. & $\begin{array}{c}t-s t \\
a t\end{array}$ & coeff. & $\begin{array}{c}t-s t \\
a t\end{array}$ & coeff. & $\begin{array}{c}t-s t \\
a t\end{array}$ & coefe. & $\begin{array}{c}t-s t \\
a t\end{array}$ \\
\hline Constant & 0.49 & 3.4 & 0.67 & 3.3 & 0.31 & 2.8 & 0.39 & 2.7 \\
\hline $\log _{Y / L}$ Initial & -0.02 & -1.1 & -0.02 & -1.0 & $-4 e-04$ & 0.0 & -0.02 & -1.2 \\
\hline log Pop.Growth & $-4 e-03$ & -0.3 & 0.01 & 0.4 & -0.01 & -0.5 & -0.01 & -0.3 \\
\hline $\begin{array}{l}\log \mathrm{H} \\
\text { Investment }\end{array}$ & 0.08 & 4.9 & 0.09 & 5.9 & 0.05 & 4.7 & 0.04 & 3.1 \\
\hline $\log$ Initial H & $-2 e-03$ & -0.2 & -0.03 & -2.1 & -0.01 & -1.0 & 0.02 & 2.2 \\
\hline $\begin{array}{l}\text { Domestic } \\
\text { Barriers }\end{array}$ & -1.05 & -3.8 & -1.32 & -4.3 & -0.97 & -4.1 & -1.31 & -4.1 \\
\hline $\begin{array}{l}\text { Foreign } \\
\text { Barriers }\end{array}$ & -0.82 & -2.0 & -1.17 & -0.2 & -0.81 & -2.0 & -0.18 & -0.2 \\
\hline$R * * 2$ & & 0.74 & & 0.72 & & 0.62 & & 0.67 \\
\hline
\end{tabular}

Notes: See data appendix for list of countries in each sample. 
Table 4: Reduced form regression on various data samples.

\begin{tabular}{|c|c|c|c|c|c|c|c|c|}
\hline & \multicolumn{8}{|c|}{ Samples } \\
\hline & \multicolumn{2}{|c|}{$\begin{array}{l}\text { Manufactures } \\
\text { Exporters } \\
\text { in } 1989 \\
\end{array}$} & \multicolumn{2}{|c|}{$\begin{array}{l}\text { Manufactures } \\
\text { Exporters } \\
\text { in } 1965\end{array}$} & \multicolumn{2}{|c|}{ Barro-Lee } & \multicolumn{2}{|c|}{$\begin{array}{l}\text { Primary Goods } \\
\text { Exporters } \\
\text { in } 1965\end{array}$} \\
\hline & \multicolumn{2}{|c|}{$(\#$ obs. $=391$} & \multicolumn{2}{|c|}{$(\#$ obs. $=20)$} & \multicolumn{2}{|c|}{$(\#$ obs. $=75)$} & \multicolumn{2}{|c|}{$(\#$ obs $=40)$} \\
\hline \multicolumn{9}{|l|}{ Reduced form } \\
\hline & coefE. & $\begin{array}{l}\text { t- } \\
\text { stat }\end{array}$ & coeff. & $\begin{array}{l}\text { t- } \\
\text { stat }\end{array}$ & coeff & $\begin{array}{l}t- \\
\text { stat }\end{array}$ & $\operatorname{coefE}$ & $\begin{array}{l}\text { t- } \\
\text { stat }\end{array}$ \\
\hline Constant & -1.18 & -0.7 & -0.79 & -0.5 & 0.49 & 0.3 & 2.60 & 1.0 \\
\hline $\log _{Y / L}$ Initial & -0.52 & -2.5 & -0.63 & -2.6 & -0.76 & -4.0 & -0.90 & -2.4 \\
\hline $\begin{array}{l}\text { log } \\
\text { Pop.Growth }\end{array}$ & $-2 e-03$ & 0.0 & -0.17 & -0.7 & -0.04 & -0.2 & 0.38 & 0.9 \\
\hline $\begin{array}{l}\log H \\
\text { Investment }\end{array}$ & 0.21 & 0.8 & 0.07 & 0.4 & 0.50 & 3.3 & 0.63 & 2.8 \\
\hline${ }_{H} \log$ Initial & 0.10 & 0.7 & 0.10 & 0.6 & 0.09 & 0.8 & 0.08 & 0.3 \\
\hline $\begin{array}{l}\text { Domestic } \\
\text { Barriers }\end{array}$ & -0.29 & -2.3 & -0.30 & -2.0 & -0.31 & -2.7 & -0.45 & -2.1 \\
\hline $\begin{array}{l}\text { Foreign } \\
\text { Earriers }\end{array}$ & -0.09 & -0.9 & -0.02 & -0.2 & -0.12 & -1.4 & -0.20 & -1.2 \\
\hline $2 \cdot 2$ & 0.30 & & 0.50 & & 0.37 & & 0.38 & \\
\hline
\end{tabular}

Notes: See data appendix for list of countries in each sample. The exact regression run was:

$$
\left(\frac{\dot{Y}}{Y}\right)_{j}=\beta_{11}-\beta_{12} \log \left(\frac{Y}{L}\right)_{j 0}-\beta_{13} \log \eta_{j}+\beta_{14} \log \left(\xi_{H}\right)_{j}-\beta_{15} O_{j} \tau^{*}-\beta_{16} O_{j} \tau .
$$

See notes on Table 1 for precise data series used. 
Table 5: Verifying robustness to inclusion of extra growth correlates.

\begin{tabular}{|c|c|c|c|c|c|c|c|c|}
\hline $\begin{array}{l}\text { Extra Growth } \\
\text { Correlates }\end{array}$ & \multirow{2}{*}{\multicolumn{2}{|c|}{$\begin{array}{l}\text { PREFERRED } \\
\text { SPECIFICATION }\end{array}$}} & \multirow{2}{*}{\multicolumn{2}{|c|}{ REVCOUP }} & \multirow{2}{*}{\multicolumn{2}{|c|}{ AVGGOVCONS }} & \multirow{2}{*}{\multicolumn{2}{|c|}{ AVGFERT }} \\
\hline \multirow{2}{*}{\multicolumn{9}{|c|}{$\begin{array}{l}\text { sample manufacture } \\
1989 \\
\text { Growth Equation }\end{array}$}} \\
\hline & & & & & & & & \\
\hline \multirow{2}{*}{ \# of observation } & \multicolumn{2}{|r|}{39} & \multicolumn{2}{|r|}{33} & \multicolumn{2}{|r|}{39} & \multicolumn{2}{|r|}{39} \\
\hline & coeff. & $\begin{array}{l}t- \\
\text { stat }\end{array}$ & coeff & $\begin{array}{l}\text { t- } \\
\text { stat }\end{array}$ & coeff. & $\begin{array}{l}\text { t- } \\
\text { stat }\end{array}$ & coeff. & $\begin{array}{l}t- \\
\text { stat }\end{array}$ \\
\hline Constant & -0.02 & -1.5 & -0.02 & -1.9 & -0.06 & -1.6 & $7 e-03$ & 0.3 \\
\hline Initial $\mathrm{x} / \mathrm{L}$ & $-4 e-06$ & -3.4 & $-3 e-06$ & -2.9 & $-4 e-05$ & -2.9 & $-4 e-05$ & -3.8 \\
\hline Pop.Growth & 0.30 & 0.9 & 0.41 & 1.3 & 0.63 & 1.3 & 1.20 & 2.5 \\
\hline$H$ Investment & -0.01 & -0.8 & -0.01 & -0.9 & -0.02 & -1.0 & -0.01 & -1.0 \\
\hline Initial $\mathrm{H}$ & $4 e-04$ & 1.8 & $4 e-04$ & 2.1 & $4 e-04$ & 1.8 & $2 e-04$ & 1.0 \\
\hline$k$ Investment & 0.24 & 6.2 & 0.23 & 6.0 & 0.33 & 3.3 & 0.20 & 3.9 \\
\hline REVCOUP & & & $4 e-04$ & 0.0 & & & & \\
\hline AVGGOVCONS & & & & & 0.11 & 1.3 & & \\
\hline AVGFERT 6084 & & & & & & & -0.01 & -1.8 \\
\hline$R * 2$ & 0.54 & & 0.62 & & 0.38 & & 0.62 & \\
\hline \multicolumn{9}{|l|}{ Investment Equation } \\
\hline & $\operatorname{coef} \mathrm{f}$ & $\begin{array}{l}\text { t-sta } \\
\end{array}$ & coeff. & $\begin{array}{l}\text { t- } \\
\text { stat }\end{array}$ & coet $\mathrm{E}$ & $\begin{array}{l}t- \\
\text { stat }\end{array}$ & coef $E$. & $\begin{array}{l}t- \\
\text { stat }\end{array}$ \\
\hline Constant & 0.50 & 3.4 & 0.48 & 2.4 & 0.37 & 3.0 & 0.77 & 4.4 \\
\hline $\log$ Initial $Y / L$ & -0.02 & -1.2 & -0.02 & -1.0 & -0.02 & -1.1 & -0.03 & -2.0 \\
\hline log Pop.Growth & $-3 e-03$ & -0.2 & $-9 e-03$ & -0.5 & -0.03 & -2.2 & 0.02 & 0.9 \\
\hline $\log H$ Investment & 0.08 & 5.0 & 0.08 & 4.0 & 0.05 & 3.1 & 0.07 & 4.7 \\
\hline $\log$ Initial $\mathrm{H}$ & $-2 e-03$ & -0.3 & $-5 e-04$ & 0.0 & $8 \mathbf{e}-04$ & 0.1 & -0.01 & -1.0 \\
\hline Domestic Barriers & -1.06 & -3.9 & -1.02 & -3.3 & -0.53 & -2.2 & -0.88 & -3.3 \\
\hline Foreign Barriers & -0.27 & -2.2 & -0.06 & -0.1 & 0.03 & 0.3 & -0.23 & -2.0 \\
\hline REVCOUP & & & -0.04 & -1.1 & & & & \\
\hline AVGGOVCONS & & & & & -0.62 & -4.2 & & \\
\hline AVGFERT 6084 & & & & & & & -0.02 & -2.3 \\
\hline $\mathrm{R} * * 2$ & & 0.74 & & 0.75 & & 0.81 & & 0.77 \\
\hline
\end{tabular}

REVCOUP $=$ number of coups and revolutions, AVGGOVCONS= average government spending as share of GDP, AVGFERT6084 = average fertility rate, 1960-1984. 
Table 6: Verifying robustness for other trade barrier proxies.

\begin{tabular}{|c|c|c|c|c|c|c|c|c|c|c|c|c|}
\hline \multicolumn{13}{|c|}{ Other Proxies for Trade Barriers, or Openness } \\
\hline $\begin{array}{c}\text { Sample: } \\
\text { Manufactures } \\
\text { exporters in } \\
1989\end{array}$ & \multicolumn{2}{|c|}{$\begin{array}{l}\text { Free Trade } \\
\text { Openness } \\
\text { Adjusted } \\
\text { Black Market } \\
\text { Premium }\end{array}$} & \multicolumn{2}{|c|}{$\begin{array}{l}\text { Free Trade } \\
\text { Openness } \\
\text { Adjusted } \\
\text { Quantitative } \\
\text { Restrictions }\end{array}$} & \multicolumn{2}{|c|}{$\begin{array}{l}\text { Leamer } \\
\text { Oponness } \\
\text { Measure } \\
\text { (LEAM1) }\end{array}$} & \multicolumn{2}{|c|}{$\begin{array}{r}\text { Leamer } \\
\text { Intervention } \\
\text { Measure } \\
\text { (LEAM2) }\end{array}$} & \multicolumn{2}{|c|}{$\begin{array}{r}\text { Exports } \\
\text { GDP } \\
\text { Ratio }\end{array}$} & \multicolumn{2}{|c|}{$\begin{array}{r}\text { Imports } \\
\text { GDP } \\
\text { Rat } 10\end{array}$} \\
\hline \multicolumn{13}{|l|}{ Growth Equation } \\
\hline \multirow[t]{2}{*}{$\#$ of observation } & \multicolumn{2}{|r|}{39} & \multicolumn{2}{|r|}{39} & \multicolumn{2}{|r|}{28} & \multicolumn{2}{|r|}{28} & \multicolumn{2}{|r|}{39} & \multicolumn{2}{|r|}{39} \\
\hline & coeff $\mathrm{f}$ & $\begin{array}{l}\text { t- } \\
\text { stat }\end{array}$ & $\operatorname{coef} \mathbf{f}$. & $\begin{array}{l}\text { E- } \\
\text { stat }\end{array}$ & coeff. & $\begin{array}{l}\text { e- } \\
\text { stat }\end{array}$ & coeff. & $\begin{array}{l}\text { :- } \\
\text { stat }\end{array}$ & coef $f$. & $\begin{array}{l}t- \\
\text { stat }\end{array}$ & coeff. & \begin{tabular}{|l}
$\mathrm{t}-$ \\
stat
\end{tabular} \\
\hline Constant & -0.02 & -1.7 & -0.02 & -1.6 & $-2 e-03$ & -0.1 & -0.01 & -1.1 & -0.02 & -1.9 & .0 .02 & -1.9 \\
\hline Initial $Y / L$ & $-4 e-06$ & -3.9 & $-4 e-06$ & -3.7 & $-4 e-06$ & -4.5 & $-4 e-06$ & -5.0 & $-4 e-06$ & -3.6 & $-4 e-06$ & -3.6 \\
\hline Pop.Growth & 0.27 & 0.8 & 0.30 & 0.9 & 0.14 & 0.5 & 0.27 & 0.9 & 0.34 & 1.0 & 0.36 & 1.1 \\
\hline H investment & -0.02 & -1.2 & -0.02 & -1.0 & -0.01 & -1.1 & -0.01 & -1.1 & -0.02 & -1.1 & -0.02 & -1.1 \\
\hline Enitial H & $5 e-04$ & 2.3 & $4 e-04$ & 2.0 & $5 e-04$ & 2.7 & $5 e-04$ & 2.9 & $4 e-04$ & 1.8 & $4 e-04$ & 1.8 \\
\hline K Investment & 0.27 & 6.6 & 0.26 & 5.9 & 0.18 & 5.3 & 0.23 & 6.9 & 0.28 & 6.3 & 0.28 & 6.4 \\
\hline$R \cdots 2$ & 0.47 & & 0.49 & & 0.61 & & 0.49 & & 0.44 & & 0.44 & \\
\hline \multicolumn{13}{|l|}{ Investment Equation } \\
\hline Constane & 0.23 & 2.0 & 0.22 & 1.5 & -0.11 & -0.7 & -0.43 & -2.2 & 0.09 & 0.6 & 0.06 & 0.4 \\
\hline $\log$ Initial $Y / L$ & 0.01 & 0.5 & 0.01 & 0.4 & 0.05 & 2.4 & 0.08 & 3.4 & 0.01 & 0.6 & 0.01 & 0.8 \\
\hline 1og pop. Growth & -0.01 & -0.4 & -0.01 & -0.3 & -0.01 & -0.4 & -0.02 & -1.1 & -0.02 & -0.8 & -0.02 & -0.9 \\
\hline L.20 $\because$ Investment & 0.05 & $3 . \mathrm{a}$ & 0.06 & 3.4 & 0.03 & 1.2 & 0.02 & 1.0 & 0.05 & 3.1 & 0.05 & 3.2 \\
\hline Lo Enitial $H$ & $-3 e-03$ & -0.3 & $5 e-03$ & 0.5 & -0.02 & -1.3 & -0.04 & -2.6 & $\therefore e-03$ & 0.4 & $4 e-03$ & 0.4 \\
\hline Domestic garriers & -0.54 & -3.5 & -0.18 & -1.0 & 0.11 & 1.6 & 0.19 & 3.9 & 0.10 & 1.8 & 0.10 & 1.9 \\
\hline Foreign Barriers & 0.11 & 0.3 & -0.71 & -1.3 & 0.66 & 1.8 & 0.30 & 1.8 & 0.02 & 0.3 & 0.11 & 0.6 \\
\hline $2 \cdot \cdots 2$ & & 0.70 & & 0.65 & & 0.62 & & 0.62 & & 0.65 & & 0.65 \\
\hline
\end{tabular}


Table 7: Alternative Trade Barriers Proxies.

\begin{tabular}{|c|c|c|c|c|c|c|}
\hline $\begin{array}{l}\text { Sample } \\
\text { Manufactures } \\
\text { Exporters in } \\
1989\end{array}$ & \multicolumn{2}{|c|}{$\begin{array}{c}\text { Survey } \\
\text { Natational } \\
\text { Protection }\end{array}$} & \multicolumn{2}{|c|}{$\begin{array}{c}\text { Survey } \\
\text { Trade } \\
\text { Legislation }\end{array}$} & \multicolumn{2}{|c|}{$\begin{array}{l}\text { Barbone } \\
\text { Openness }\end{array}$} \\
\hline \multicolumn{7}{|l|}{ Growth Equation } \\
\hline \multirow{2}{*}{$\begin{array}{l}\# \text { of } \\
\text { observation }\end{array}$} & 23 & & 23 & & 16 & \\
\hline & coeff. & t-stat & coeff. & t-stat & coeff. & t-stat \\
\hline Constant & 0.01 & 0.8 & -0.03 & -1.4 & 0.03 & 5.2 \\
\hline Initial $Y / L$ & $-4 e-06$ & -3.6 & $-4 e-06$ & -3.0 & $-4 e-06$ & -9.1 \\
\hline Pop. Growth & 0.10 & 0.3 & 0.49 & 1.4 & 0.47 & 1.8 \\
\hline $\mathrm{H}$ Investment & -0.01 & -0.4 & -0.02 & -1.2 & 0.01 & 1.4 \\
\hline Initial $\mathrm{H}$ & $5 e-04$ & 2.4 & $5 e-04$ & 2.6 & $1 e-04$ & 1.5 \\
\hline$K$ Investment & 0.12 & 1.9 & 0.27 & 4.6 & 0.04 & 1.8 \\
\hline $\mathrm{R} \star \star 2$ & & 0.56 & & 0.36 & & 0.90 \\
\hline \multicolumn{7}{|c|}{ Investment Equation } \\
\hline Constant & 0.28 & 1.4 & 0.22 & 1.1 & 0.71 & 2.9 \\
\hline $\begin{array}{l}\log \text { Initial } \\
Y / L\end{array}$ & $5 e-03$ & 0.2 & $-3 e-03$ & -0.2 & -0.02 & -1.0 \\
\hline log Pop. Growth & -0.01 & -0.2 & -0.02 & -0.6 & 0.02 & 0.9 \\
\hline $\begin{array}{l}\log \mathrm{H} \\
\text { Investment }\end{array}$ & 0.04 & 1.8 & 0.04 & 1.6 & 0.09 & 2.5 \\
\hline $\log$ Initial $\mathrm{H}$ & $-2 e-03$ & -0.1 & $-3 e-03$ & -0.2 & -0.02 & -1.4 \\
\hline $\begin{array}{l}\text { Domestic } \\
\text { Barriers }\end{array}$ & $-5 e-04$ & -0.4 & $8 e-04$ & 1.0 & -0.03 & -0.4 \\
\hline $\begin{array}{l}\text { Eoreign } \\
\text { Barriers }\end{array}$ & $-3 e-04$ & -0.5 & $-2 e-04$ & -0.3 & -1.60 & -1.6 \\
\hline $\mathrm{R} * \star 2$ & & 0.41 & & 0.40 & & 0.36 \\
\hline
\end{tabular}

Alternative trade barrier proxies from De Long and Summers (1991).

The Barbone measure is based on residuals from an estimated gravity model (for OECD countries only.

The Survey indices are from world Competitiveness Report. 
Table 8: Trade variables in both growth and investment equations.

\begin{tabular}{|c|c|c|c|c|c|c|c|c|}
\hline \multicolumn{9}{|c|}{ Samples } \\
\hline & \multicolumn{2}{|c|}{$\begin{array}{l}\text { Manufactures } \\
\text { Exporters } \\
\text { in } 1989 \\
\end{array}$} & \multicolumn{2}{|c|}{$\begin{array}{l}\text { Manufactures } \\
\text { Firporters } \\
\text { in } 1965 \\
\end{array}$} & \multicolumn{2}{|c|}{ Barro-teo } & \multicolumn{2}{|c|}{$\begin{array}{l}\text { Primary Goods } \\
\text { Exportors } \\
\text { in } 1965 \\
\end{array}$} \\
\hline & \multicolumn{2}{|c|}{$(\#$ obs.$=39)$} & \multicolumn{2}{|c|}{$(\#$ obs. $=20\}$} & \multicolumn{2}{|c|}{$(\#$ obs. $=75)$} & \multicolumn{2}{|c|}{$(\#$ obs.$=40)$} \\
\hline \multicolumn{9}{|l|}{ Growth Equation } \\
\hline & coeff. & t-stat & coeff. & $t-s t a t$ & coeft. & t-stat & coeft. & t-stat \\
\hline Constant & -0.03 & -2.4 & -0.03 & -2.4 & -0.01 & -0.7 & -0.01 & -0.9 \\
\hline Initial $\mathrm{Y} / \mathrm{L}$ & $-3 e-06$ & -2.5 & $-6 e-06$ & -4.1 & $-4 e-06$ & -3.3 & $-5 e-06$ & -2.1 \\
\hline Pop. Growth & 0.23 & 0.7 & 1.76 & 2.9 & -0.18 & -0.7 & -0.10 & -0.3 \\
\hline$H$ Investment & -0.04 & -1.9 & -0.02 & -1.2 & -0.01 & -0.3 & $5 e-03$ & 0.1 \\
\hline Initial $\mathrm{H}$ & $5 e-04$ & 2.0 & $9 e-04$ & 2.8 & $3 e-04$ & 1.4 & $3 e-05$ & 0.1 \\
\hline$K$ Investment & 0.32 & 6.3 & 0.30 & 7.1 & 0.22 & 2.2 & 0.21 & 3.1 \\
\hline $\begin{array}{l}\text { Bomest ic } \\
\text { Barriers }\end{array}$ & 0.13 & 1.6 & -0.16 & -2.3 & 0.09 & 0.8 & 0.13 & 1.2 \\
\hline Foreign Barriers & 0.21 & 1.9 & -3.23 & -1.7 & 0.09 & 0.8 & -0.07 & -0.4 \\
\hline$R * * 2$ & & 0.39 & & 0.62 & & 0.36 & & 0.61 \\
\hline \multicolumn{9}{|c|}{ Investment Equation } \\
\hline Constant & 0.50 & 3.5 & 0.48 & 2.1 & 0.34 & 3.1 & 0.42 & 2.9 \\
\hline $\log$ Initial $\mathrm{x} / \mathrm{L}$ & -0.02 & -1.3 & -0.01 & -0.3 & -0.01 & -0.4 & -0.02 & $-1 \cdot 3$ \\
\hline log Pop.Growth & -0.01 & -0.4 & $-6 e-03$ & -0.3 & -0.01 & -0.7 & -0.01 & -0.3 \\
\hline $10 \mathrm{or} \mathrm{H}$ Investment & 0.07 & 4.8 & 0.09 & 5.6 & 0.05 & 4.9 & 0.04 & 3.3 \\
\hline log initial $\mathrm{H}$ & $-1 e-03$ & -0.1 & -0.04 & -2.4 & -0.01 & -0.7 & 0.02 & 2.1 \\
\hline $\begin{array}{l}\text { Domestic } \\
\text { Barriers }\end{array}$ & -1.12 & -4.0 & -0.98 & -2.7 & -1.00 & -4.3 & -1.29 & -4.1 \\
\hline Foreign Barriers & -1.04 & -2.5 & 4.53 & 0.8 & -0.84 & -2.1 & -0.25 & -0.3 \\
\hline$R * * 2$ & & 0.74 & & 0.73 & & 0.61 & & 0.67 \\
\hline
\end{tabular}

